\title{
UJI EFEKTIVITAS EMPAT VARIASI PROPOLIS TRAP TERHADAP PRODUKSI PROPOLIS LEBAH MADU Apis mellifera L.
}

\author{
The Effectivity Test of Four Propolis Traps Variations on Propolis Production of Apis Mellifera L. Honey \\ Bees
}

\author{
Budiaman and Arief Rahman
}

\begin{abstract}
The propolis produced by honeybees as it is used a material for cosmetic and health industry fiberglassconstructed has high economy value. However, the effective methode for the propolis production has not been found. The objective of this research was to find out the effectiveness of four propolis traps variations on the propolis production of Apis mellifera honeybees. Materials used in this research were sixteen colony of Apis mellifera honeybees and propolis traps. The propolis production and the formed surface area on traps were collected from four trap treatments with four replications. The obtained data were analyzed by using Completely Random Design Analysis and Tukey Test. The most effective of propolis traps was that made of fiberglasses with hole direction same as frame direction (the average production of $2.03 \mathrm{~g}$ ). The largest of propolis surface area was produced by propolis trap with hole direction same as frame direction $\left(28.29 \mathrm{~cm}^{2}\right)$. No corellation between the large of propolis survace $\left(\mathrm{cm}^{2}\right)$ and propolis production (g) was observed.
\end{abstract}

Keywords: honeybees, propolis traps, propolis production.

\section{PENDAHULUAN}

Apis mellifera $\mathrm{L}$, merupakan salah satu dari spesies lebah madu yang memiliki sifat yang unggul dengan produksi madu dan daya adaptasinya yang cukup tinggi. Lebah unggul ini memiliki sifat yang memungkinkan untuk diternakkan ke arah pengembangan yang bernilai komersil. Produk lebah madu tidak hanya terbatas pada madu saja, tetapi lebah madu memiliki banyak manfaat baik manfaat langsung maupun manfaat tidak langsung. Beberapa hasil produk lungsung dari lebah madu yang bernilai komersil yaitu madu, lilin lebah, pollen, bee venom, royal jelly dan propolis. Propolis merupakan salah satu produk yang bernilai ekonomi tinggi, dengan nilai jual saat ini yang mencapai Rp. 600 - 700.- ribu per kg.

Propolis yang dikenal sebagai lem lebah merupakan bahan liat dan kaku yang rnengandung resin, memiliki bau aromatik, pada suhu di bawah $15^{\circ} \mathrm{C}$ akan mengeras, menjadi liat dan lengket pada suhu $36^{\circ} \mathrm{C}$, dan akan meleleh menjadi cairan yang lekat pada suhu $60-70^{\circ} \mathrm{C}$. Berat jenisnya bervariasi tergantung dari jenis tanaman yang dikoleksi yaitu berkisar dari 1,1112 sampai 1,136. Propolis tidak larut dalam air, sedikit larut dalam terpentin, sebagian larut dalam alkohol, dan mudah larut dalam eter dan kloroform (Yaouchun, 1993).

Propolis yang dikumpulkan oleh lebah pekerja lapangan untuk digunakan sebagai penutup celah stup atau sisiran, menempel lubang-lubang kecil untuk perlindungan diri dari musuh alami terutama bakteri dan virus. Selain berguna bagi masyarakat lebah, propolis juga berguna bagi manusia. Sejumlah hasil penelitian menunjukan bahwa propolis mempunyai sifat antibiotik sehingga dapat menghambat pertumbuhan bakteri dan jamur. Propolis juga memiliki bius lokal yang dapat digunakan untuk pengobatan berbagai macam penyakit antara lain pengobatan infeksi pada mulut, tenggorokan, hidung, sinus, tonsil dan asma, pengobatan prostat daerah jantung dan organ lain yang berhubungan dengan saluran urine, pengobatan flu dan demam, pengobatan kanker dan bronkhitis, pengobatan penyakit parkinson, pengobatan gastric ulcer dan pengobatan penyakit ginekologi dan tumor (Yaouchun. 1993).

Pemanfaatan plastik sebagai bahan dasar propolis trap yang digunakan sebelumya dinilai kurang efektif, dimana berat rata-rata propolis tertinggi yang dihasilkan setiap 
pemanenan per 10 hari yaitu 1,2025 g. Penerapan teknologi tepat guna dalam hal ini penggunaan fiberglass sebagai bahan dasar pembuatan perangkap propolis merupakan salah satu alternatif yang diniliai cocok dalam upaya meningkatkan produksi propolis. Sitatnya yang tahan karat, tahan terhadap zat asam. tidak terlalu berbau, berat jenisnya lebih kecil dari alumunium dan baja dan pengerjaan serta pengolahannya mudah. Selain itu juga dengan mengganti komposisi kimia dan merubah bahan penguatnya, bentuk fiberglass yang dihasilkan dapat didesain sesuai dengan aplikasi yang berbeda

Berdasarkan uraian di atas, maka perlu dilakukan penelitian mengenai Uji efektifitas empat variasi propolis trap terhadap produksi propolis Lebah Apis mellifera L

Penelitian ini bertujuan untuk mengetahui efektifitas empat variasi propolis trap yang diperbandingkan terhadap produksi propolis. Penelitian ini diharapkan dapat menjadi bahan infomasi bagi peternak lebah madu dan pihak-pihak lain yang berkepentingan sehubungan dengan upaya pemanenan Propolis dengan Propolis Trap.

\section{BAHAN DAN METODE}

1. Menyiapkan 16 koloni lebah madu Apis mellifera $\mathrm{L}$ yang kuat.

2. Propolis trap dipasang pada masing-masing kotak sarang, tepatnya di antara kotak sarang dan penutup luar sarang, seperti terlihat pada Gambar 1 . Propolis trap dengan arah lubang searah dengan arah frame dipasang pada koloni lebah 1,9,10, dan 16, propolis trap dengan arah memotong arah frame dipasang pada koloni lebah 6.8,13. dan 14, propolis trap dengan arah lubang diagonal dipasang pada koloni lebah 5,7,11. dan 15 dan propolis trap dari plastik dipasang pada koloni 2, 3, 4 dan 12

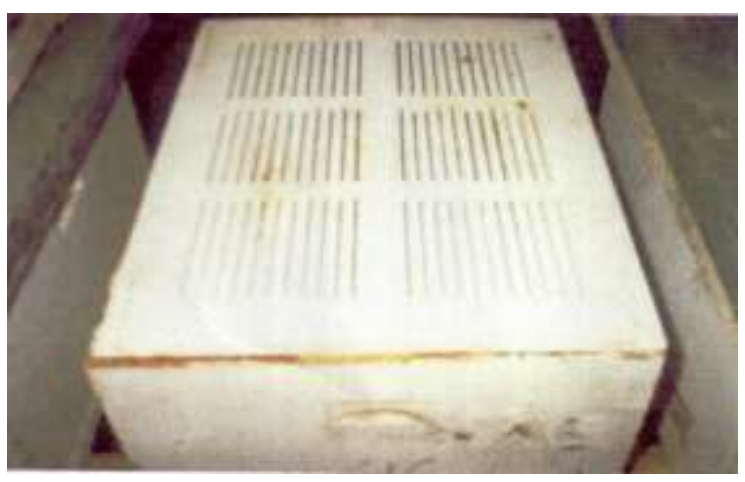

Figure 1. Setting of a pollen trap
3. Propolis trap diambil pada tiap hari ke sepuluh (10) dengan menghitung luas permukaan yang tertutupi oleh propolis kemudian mengambil propolisnya dan dilakukan sebanyak 4 kali

4. Propolis yang telah dikeluarkan dari masingmasing propolis trapnya dimasukkan ke dalam plastik dan diberi label.

5. Propolis yang dihasilkan ditimbang beratnya dan dikurangi dengan berat plastik.

6. Variabel yang diamati dalam penelitian ini adalah banyaknya propolis yang diperoleh dari setiap koloni sesuai dengan perlakuan dan luas permukaan prapolis. Berat propolis dihitung dengan mengunakan rumus:

$$
A=B-C
$$

$A=$ berat propolis $(g)$

$B=$ Berat plarstik + berat propolis

$\mathrm{C}=$ berat plastik

7. Rancangan percobaan yang digunakan dalam penelitian adalah Rancangan Acak Lengkap (RAL) dengan 4 perlakuan dan 4 ulangan, yaitu :

A : Propolis trap dari fiberglass dengan arah lubang sejajar arah frame

B : Propolis trap dari fiber glass dengan arah lubang horizontal atau memotong arah frame.

C : Propolis trap dari fiber glass dengan arah lubang diagonal

D : propolis trap dari plastik dengan arah lubang searah dengan arah frame (sebagai kontrol)

Menurut Gaspersz (1989) bahwa model matematis RAL adalah sebagai berikut :

$$
Y_{i j}=\mu+T i+\varepsilon_{i j k}
$$

\section{HASIL DAN PEMBAHASAN}

\section{Tingkat Produksi Propolis pada masing- masing Perlakuan}

Hasil analisis data menujukkan bahwa propolis trap yang terbuat dari fiberglass dengan arah lubang searah dengan arah frame lebih efektif dibanding dengan perangkap propolis yang terbuat dari plastik (kontrol), perangkap propolis dengan arah lubang memotong arah frame dan arahnya diogonal. Hal ini dibuktikan dengan data hasil produksi propolis tertinggi terdapat pada perlakuan arah lubang searah dengan arah frame yaitu sebesar 2,03 g, kemudian propolis trap dari 
plastik sebagai kontrol sebesar $1,71 \mathrm{~g}$, perlakuan arah lubang memotong arah frame sebesar $0,81 \mathrm{~g}$ dan terendah pada perlakuan arah lubang diagonal sebesar 0,7 g (Gambar 2)

Tingkat produksi propolis lebah Apis mellifera $\mathrm{L}$ yang lebih tinggi pada perlakuan arah lubang searah dengan arah frame dibanding dengan perlakuan lainnya. Ini disebabkan karena lebah tidak mengalami kesulitan dalam menutupi celah atau lubang yang terdapat dalam sisiran maupun sarang dengan arah lubang yang sejajar dengan arah frame, pada dasarnya mekanisme kerja atau alur kerja lebah mengikuti arah frame yang ada pada sarangnya, dengan kata lain lebah beraktifitas pada masing-masing frame, sehingga apabila celah-celah atau lubang yang terdapat pada sisiran atau sarang arahnya memotong arah frame atau arahnya diagonal maka lebah akan mengalami kesulitan dan lebah akan mengalami stress, cirinya yaitu lebah pekerja lebih banyak berdiam dalam sarang dibanding terbang untuk mengambil propolis sehinggga lubang yang ada hanya sedikit yang tertutupi oleh propolis. Secara umum produksi propolis sangat dipengaruhi oleh kondisi tanaman pengahasil getah di sekitarnya. Hal ini sejalan dengan apa yang dikemukam oleh Walji (1996) bahwa jagung merupakan tanaman bawah yang tidak berkayu dan hanya memproduksi sedikit getah pada bagian pucuk daun.

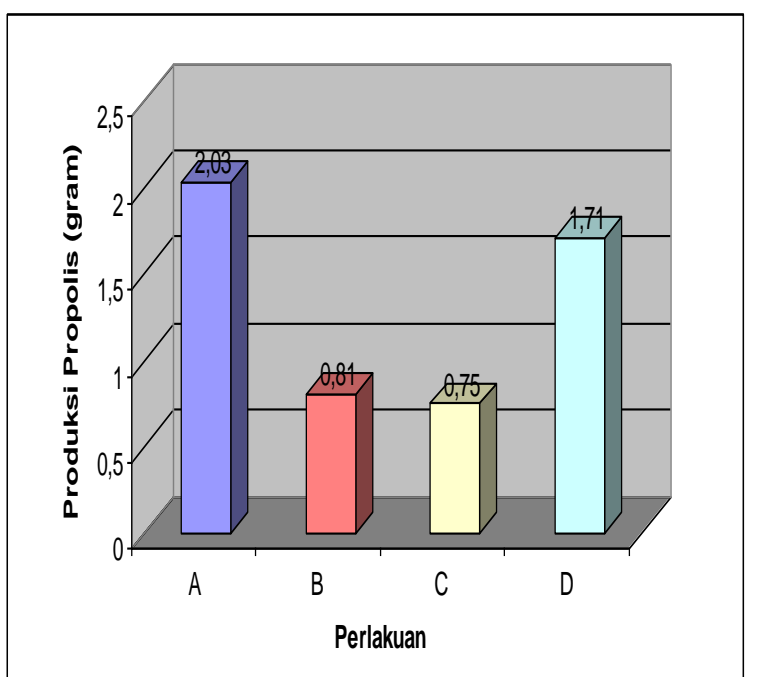

Figure 2. Average production of propolis

cairan yang dihasilkan oleh kelenjar nektar tumbuhan. Selanjutnya Dietz (1984) mengemukan bahwa lebah pekerja yang sedang terbang memerlukan rata-rata $10 \mathrm{mg}$ gula per jam, lima diantara tujuh jenis gula yang dibutuhkan oleh lebah madu (glukosa, fruktosa, melezitose, sukrosa dan maltose) terdapat dalam nektar. Disamping itu, persediaan lemak dalam tubuh lebah sangat mempengaruhi aktifitas terbang lebah dalam mengumpulkan propolis. Sihombing (1997) mengemukakan bahwa cadangan lemak merupakan energi yang mempunyai keistimewaan. Sammataro dan Avitabile (1978) menjelaskan bahwa sifat ini esensial untuk terbang yang dikendalikan oleh dua pasang sayap yang terdapat pada bagian thorax. Disamping itu lebah pekerja memiliki tungkai yang merupakan struktur yang telah mengalami spesialisasi yang membantunya dalam membersihkan tubuh dan mengumpulkan propolis.

\section{Luas Permukaan Propolis yang Terbentuk pada Propolis Trap}

Perbedaan luas permukaan propolis yang terbentuk pada propolis trap dari masing-masing perlakuan disebabkan oleh arah lubang perangkap propolis yang berbeda-beda, dimana arah lubang yang searah dengan arah frame memberikan kemudahan bagi lebah dalam menutupinya. Hubungan antara luas permukaan propolis yang terbentuk dengan produksi propolis tidak ada yang saling mempengaruhi. Hal ini dilihat dari hasil analisis data yang menunjukkan tidak ada hubungan yang saling mempengaruhi antara luas permukaan propolis yang terbentuk dengan produksi propolis (t hitung $<\mathrm{t}$ tabel). Pada produksi propolis, perlakuan arah lubang memotong arah frame berada pada urutan ketiga setelah propolis trap dari plastik dengan nilai sebesar 16,532 $\mathrm{cm}^{2}$ sedangkan pada luas permukaan propolis yang terbentuk pada perlakuan arah lubang memotong arah frame berada pada urutan keempat setelah propolis trap dengan arah lubang diagonal dengan nilai $13,4625 \mathrm{~cm}^{2}$. Dengan demikian luas pemukaan propolis tidak berbanding lurus dengan tingkat produksi propolis (g). Dadan and Sons menjelaskan bahwa propolis dibawa oleh lebah pekerja ke dalam stupnya dalam bentuk butiran di dalam sel atau lubang kerak yang terbentuk atau celah dengan sebaran yang tidak merata. Morse (1976) menambahkan bahwa untuk mengumpulkan dan memanipulasi propolis adalah tidak mudah bagi lebah, sebab bahan ini 
lengket dan bergetah, sehingga sulit mengatur penyebarannya secara merata.

\section{KESIMPULAN}

1. Propolis trap yang paling efektif yaitu propolis trap dari fiberglass dengan arah lubang searah dengan arah frame dengan produksi rata-rata propolis tertinggi sebesar $2,03 \mathrm{~g}$.

2. Luas permukaan propolis yang terbentuk ratarata terluas dihasilkan oleh propolis trap dengan arah lubang searah dengan arah frame dengan luas $28,29 \mathrm{~cm}^{2}$, kemudian propolis trap dari plastik dengan luas sebesar $16,885 \mathrm{~cm}^{2}$, selanjutnya propolis trap dengan arah lubang diagonal dengan luas $16,5325 \mathrm{~cm}^{2}$, dan terendah pada propolis trap dengan arah lubang memotong arah frame yaitu sebesar 13,4625 $\mathrm{cm}^{2}$

\section{DAFTAR PUSTAKA}

Dadan and Sons (edts), 1989. The Hive and The Honey Bee. Dadant dan Sons, Inc. USA.
Dietz. A. 1984. Nutrition of the Adult Honey Bee, dalam Dadant \& Sons.Tthe Hive and The Honey Bee. Journal Printing Company, Illinois, USA. pp. 125 - 147

Gaspersz, V.,1989. Metode Perancangan Percobaan untuk Ilmu-ilmu Pertanian, Tehnik dan Biologi. Armico. Bandung.

Morse, A.R.. 1976. Bee and Beekeeping. Cornel University Press. Ithaca and London.

Sammataro dan Avitabile, 1978. Beekeeper"s Hand Book. Peach Montain Press. Dexter Michigan.

Sihombing. D.T.H. 1997. Ilmu Ternak Lebah Madu. Gadjah Mada University Press.

Yaouchun, C. 1993. Apiculture in China, Agricultural Publishing, House, Beijing.

Walji H. 1996. Terapi Lebah dengan Kekuatan dan Khasiat Lebah Madu dan Serbuk Sari. Prestasi Pustaka Publisher. Jakarta.

Diterima : 01Juni 2006

Budiaman

Lab. Serangga Berguna, Jurusan Kehutanan, Universitas Hasanuddin

Kampus Tamalanrea, Jl. Perintis Kemerdekaan Km. 10, Makassar 90245

Telp./Fax. 0411-585917. Indonesia

\section{Arief Rahman}

Alumni Jurusan Kehutanan, Universitas Hasanuddin

Staf PT. Riau Andalas Pulp and Paper 